\title{
LEO SMITH
}




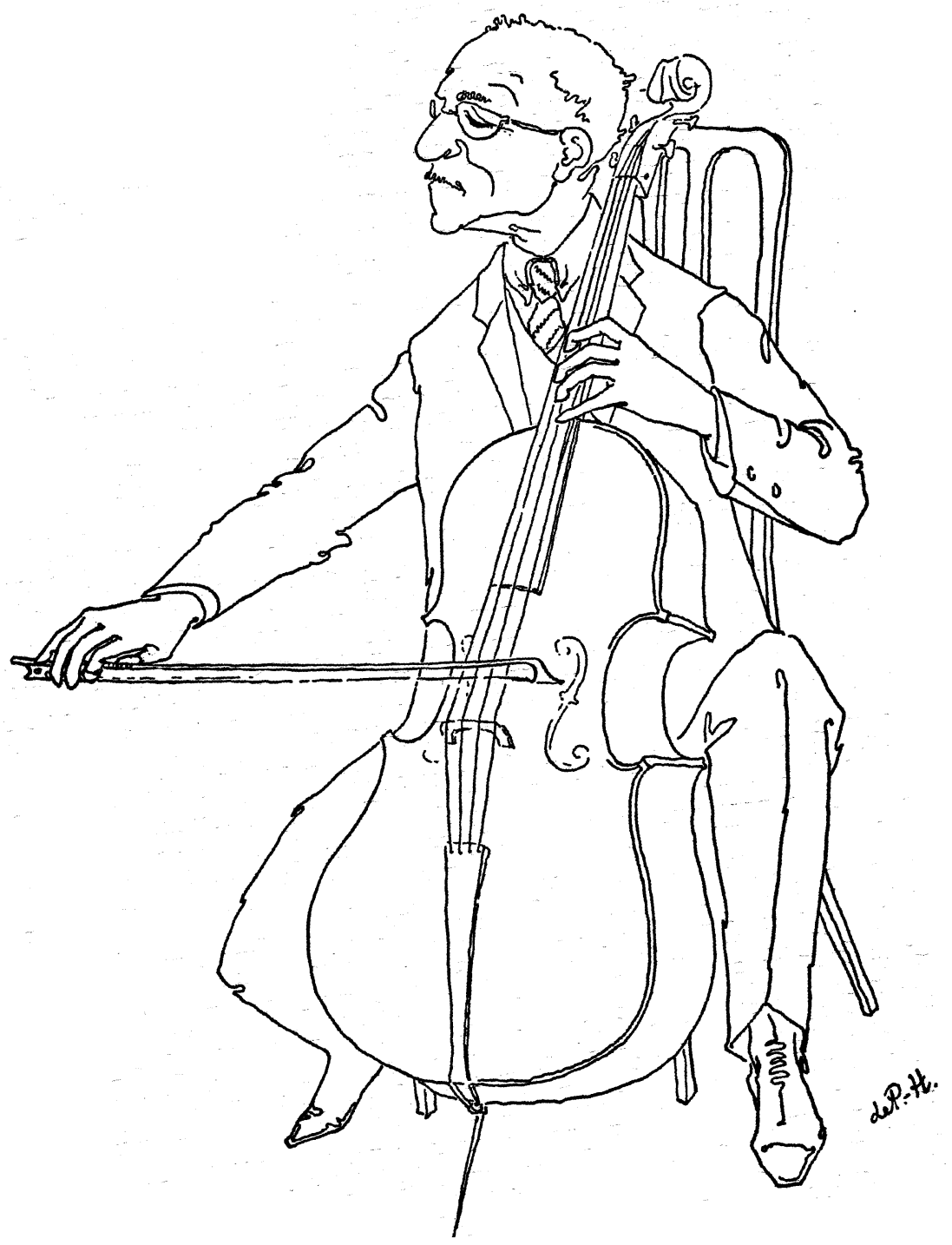




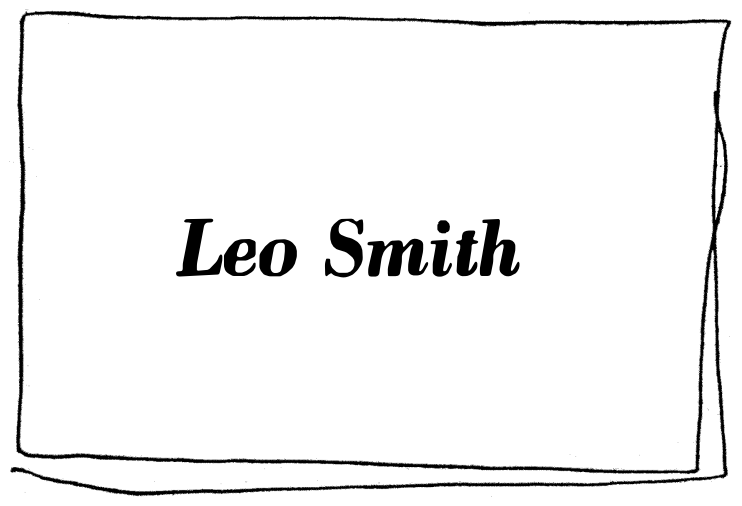

A Biographical Sketch by

Pearl McCarthy

UNIVERSITY OF TORONTO PRESS 
Copyright (C), Canada, 1956, by University of Toronto Press

Reprinted 2017

ISBN 978-1-4875-8695-9 (paper) 